không cổ điển 100\%), kết quả cho thây rằng bất kỳ mức độ ảnh hưởng đến hoạt độ enzyme 21 Hydroxylase nào đều gây ảnh hưởng đến phát triển giới tính ở trẻ nữ.

Cơn suy thượng thân cấp chỉ được ghi nhận ở các bệnh nhân thể mất muối, trong đó tần suất xuất hiện ở nam cao hơn ở nữ $(91,8 \%$ so với $78,6 \%)$. Điều này được lý giải do trẻ nữ thể mất muối khi sinh ra có biểu hiện sinh lý ngoài bất thường bộ phận sinh dục, do vậy sẽ được chẩn đoán sớm hơn và nhiều khả năng dự phòng được cớn suy thượng thận cấp hơn so với trẻ nam.

Tỉ lệ giới tính có sự khác biệt nhau giữa các thể bệnh, trong đó mất muối có tỉ lệ nam/nữ gần tương đương nhau (nam $46,6 \%$ và nữ $54,4 \%)$; thể nam hóa đơn thuần có tỉ lệ bệnh nhân nữ cao $(81,8 \%)$ hơn so với nam giới $(18,2 \%)$. Bệnh tăng sản thượng thận là bệnh di truyền lặn nhiễm sắc thể thường, do đó về lý thuyết tỉ lệ mắc bênh ở nam và nữ là tương đương nhau. Giải thích cho sự chênh lệch này ở thể nam hóa đơn thuần là do trẻ nam thể nam hóa đơn thuần không có các biểu hiện lâm sàng rõ rệt ngoài dậy thì sớm, do vậy thường không được coi là bất thường và ít được tiếp cận chẩn đoán hơn so với trẻ nữ [8].

\section{KẾT LUÂN}

Qua nghiên cứu đă̆c điểm lâm sàng của 209 bệnh nhân tăng sản thượng thận bẩm sinh thiếu enzym 21-hydroxylase cho thấy: phát hiện được $77 \%$ bệnh nhân mắc thể mất muối, $21 \%$ thể nam hóa đơn thuần chiếm và $2 \%$ mắc thể không cổ điển. Bệnh nhân thể mất muối và thể không cổ điển được chẩn đoán sớm hơn (32 ngày và 18,5 ngày) so với bệnh nhân thể nam hóa đơn thuần $(1590$ ngày) $(p<0.001)$.
Lời cám ơn. Nghiên cứu được thực hiện sự giúp đõ̃ của các cán bộ của Trung tầm nghiên cứu Gen- Protein, Bộ môn Nhi, Trường Đại học $Y$ Hà Nội; Khoa Nội tiết-Chuyển hóa- Di truyền,Bệnh viện Nhi Trung ương.

\section{TÀI LIỆU THAM KHẢO}

1. Gonçalves J., Friães A., và Moura L. (2007). Congenital adrenal hyperplasia: focus on the molecular basis of 21-hydroxylase deficiency. Expert Rev Mol Med, 9(11), 1-23.

2. White P.C. (2000). Congenital Adrenal Hyperplasia due to 21-Hydroxylase Deficiency. Endocr Rev, 21(3), 245-291.

3. Krone N. và Arlt W. (2009). Genetics of congenital adrenal hyperplasia. Best Pract Res Clin Endocrinol Metab, 23(2), 181-192.

4. Merke D.P. và Bornstein S.R. (2005). Congenital adrenal hyperplasia. The Lancet, 365(9477), 2125-2136.

5. Choi J.-H., Jin H.-Y., Lee B.H. và cộng sự. (2012). Clinical phenotype and mutation spectrum of the CYP21A2 gene in patients with steroid 21-hydroxylase deficiency. Exp Clin Endocrinol Diabetes Off J Ger Soc Endocrinol Ger Diabetes Assoc, 120(1), 23-27.

6. Krone N., Braun A., Roscher A.A. và công sư (2000). Predicting phenotype in steroid 21hydroxylase deficiency? Comprehensive genotyping in 155 unrelated, well defined patients from southern Germany. J Clin Endocrinol Metab, 85(3), 1059-1065.

7. Dolzan V., Sólyom J., Fekete G. và cộng sự (2005). Mutational spectrum of steroid 21hydroxylase and the genotype-phenotype association in Middle European patients with congenital adrenal hyperplasia. Eur J Endocrinol, 153(1), 99-106.

8. Rafał Podgórski, David Aebisher, Monika Stompor, Dominika Podgórska, Artur Mazur (2018). Congenital adrenal hyperplasia: clinical symptoms and diagnostic methods. Acta Biochim Pol., 65(1),25-33.

\title{
PHÂN TÍCH THUỐC KHÁNG SINH SỬ DUUNG TẠI BỆNH VIỆN ĐA KHOA HUYỆN VĨNH THUÂ̂N, TỈNH KIỀN GIANG NĂM 2018
}

\section{TÓM TẮT}

Đă̆t vấn đề: Theo dõi tình hình sử dụng kháng sinh tại bệnh viện thông qua phân tích danh mục các

\footnotetext{
${ }^{1}$ Trường Đại học Dược Hà Nội

${ }^{2}$ Bênh viên đa khoa huyên Vỉnh Thuân, tỉnh Kiên Giang Chịu trách nhiệm chính: Nguyễn Thị Thanh Hương Email: thanhhuong.duochn@gmail.com

Ngày nhận bài: 22.12.2020

Ngày phản biên khoa hoc: 26.01.2021

Ngày duyệt bài: 9.2.2021
}

\section{Nguyễn Thị Thanh Hương ${ }^{1}$, Trần Thành Trung ${ }^{2}$}

thuốc kháng sinh đã sử dụng giúp bệnh viện có giải pháp quản lý kip thời việc mua sắm, kê đ̛ơn thuốc kháng sinh tại bệnh viện. Mục tiêu của nghiên cứu là mô tả cơ cấu danh mục thuốc kháng sinh sử dung nhằm chỉ ra một số tồn tại trong sử dụng kháng sinh tại bệnh viện thông qua một số chỉ số đánh giá, từ đó định hướng trong công tác quản lý sử dụng kháng sinh. Đối tượng và phương pháp: 56 thuốc kháng sinh được sử dung năm 2018 tai bệnh viện đa khoa huyện Vĩnh Thuận, tỉnh Kiên Giang (toàn bộ thuốc kháng sinh đã xuất kho từ 1/1/2018 đến 31/12/2018 tại khoa Dược bệnh viện). Phương pháp nghiên 
cứu: mô tả cắt ngang. Kết quả: 56 thuốc kháng sinh sử dung trong số 410 khoản muc thuốc đã sử dung (chiếm 13,4\%) với giá trị 4,322 tỷ đồng (chiếm 27,3\% tổng chi phí tiền thuốc). Thuốc sản xuất trong nước chiếm 85,13\% giá trị; 83,93\% khoản mục. Đối tượng ngoại trú chiếm $64,86 \%$ giá trị. Thuốc đớn thành phần chiếm 99,93\% giá trị; $96,43 \%$ khoản muc. Thuốc đường tiêm chiếm $23,05 \%$ giá trị. Kháng sinh cephalosporin chiếm $52,28 \%$ giá trị. Ceftazidim, ceftizoxim và ceftriaxon là những kháng sinh đường tiêm được sử dụng với số lượng và giá trị nhiều nhất. Số DDD kháng sinh/100 giường - ngày là 35,835, phân nhóm cephalosporin cao nhất (27,556 DDD). Số DDD/bệnh nhân của một số kháng sinh khảo sát thấp gồm: ceftazidim (1,55 DDD), ceftizoxim (1,71 DDD), cefuroxim $(1,79 \mathrm{DDD})$, cefotaxim (1,19 DDD), cefixim $(0,84$ DDD). Kết luận: Kháng sinh cephalosporin được sử dụng nhiều như ceftazidim, ceftizoxim và ceftriaxon. Một số kháng sinh có thời gian sử dụng chưa hợp lý như ceftazidim, ceftizoxim, cefuroxim, cefotaxim, cefixim.

\section{SUMMARY \\ ANALYSIS OF ANTIBIOTIC CONSUMPTION AT VINH THUAN GENERAL HOSPITAL, KIEN GIANG PROVINCE IN 2018}

Background and objective: Antibiotic drugs use surveillance by analyzing drugs used can support appropriate drug procurement and prescription in hospitals. The main objective is to describe antibiotic items used in order to point out some shortcomings in the use of antibiotics in the hospital through a number of evaluation indicators, thereby guiding the management of antibiotic use. Methods: This is a cross-sectional study on 56 antibiotics used at Vinh Thuan General Hospital, Kien Giang province. The data were extracted from the stock records of the hospital's Department of Pharmacy from 01/01/2018 to $31 / 12 / 2018)$. Results: Out of 410 total items used, $56(13.4 \%)$ were antibiotics with a total value of 4.322 billion VND (27.3\% total drugs expense). Domestic drugs accounted for $85.13 \%$ of total value and $83.93 \%$ of total item counts. Drugs used for outpatient care responsible for $64.86 \%$ total drug expense. $99.93 \%$ of total drug expense and $96.43 \%$ of drug items used were prescription drugs. Injection drugs accounted for $23.05 \%$ total drug costs. Cephalosporin antibiotics had $52.28 \%$ of total drug expense. Ceftazidim, ceftizoxim and ceftriaxon were the most frequently used and had the highest costs injecting antibiotics. Antibiotic DDD/100 bed - day was 35.835 , the cephalosporin subgroup was highest, at 27.556. Other lower DDD/patient antibiotics were: ceitazadim (1.55 DDD), ceftizoxim (1.71 DDD), cefuroxim (1.79 DDD), cefotaxim (1.19 DDD) and cefixim (0.84 DDD). Conclusions: Cephalosporin antibiotics are widely used such as ceftazidim, ceftizoxim and ceftriaxon. Some antibiotics have unusuable period of time such as ceftazidim, ceftizoxim, cefuroxim, cefotaxim, cefixim.

Keywords: antibiotic, DDD, Vinh Thuan, hospital Kien Giang province.

\section{I. ĐĂT VẤN ĐỀ}

Kháng sinh là thuốc điều trị nhiễm khuẩn và nếu sử dụng không hợp lý sẽ gây ra tình trạng vi khuẩn kháng kháng sinh. Nguy cơ kháng kháng sinh là thách thức đối với các quốc gia trong đó có Việt Nam. Tỷ lê chi phí thuốc kháng sinh còn chiếm khoảng $30 \%$ đến $40 \%$ tổng chi tiền thuốc tại bệnh viện ${ }^{[3][5]}$. Hội đồng thuốc và điều trị bệnh viện có nhiệm vụ giám sát các thuốc sử dụng tại bệnh viện, trong đó có thuốc kháng sinh thồng qua các hoạt động đánh giá thuốc sử dụng đã được Bộ y tế ban hành, chỉ số DDD (Defined Daily Dose)/100 giường - ngày được khuyến cáo áp dungg ${ }^{[1]}$. Đối với thuốc kháng sinh cân có hướng dẫn cụ thể giúp các cơ sở y tế sử dụng hợp lý hơn nhóm thuốc này, đến nay Hướng dẩn thực hiện quản lý kháng sinh trong bênh viện (Quyết định 5631) trong đó có yêu cầu các bệnh viện cần xây dựng danh mục kháng sinh cần ưu tiên quản lý, theo dõi tinh hình sử dụng kháng sinh qua chi phí mua kháng sinh và số DDD/100 hoặc 1000 giường - ngày ${ }^{[2]}$.

Bệnh viện đa khoa huyện Vĩnh Thuận, tỉnh Kiên Giang là Bệnh viện đa khoa hạng II với quy mô 300 giường kế hoạch, mỗi ngày bệnh viện khám và điêu trị cho từ 500 - 600 bênh nhân ngoại trú và 300 - 400 bệnh nhân nội trú. Hàng năm tổng chi tiền thuốc tại bệnh viện hơn 14 tỷ đồng, trong đó tiền thuốc kháng sinh chiếm khoảng $30 \%$. Với đặc thù là bệnh viện đa khoa tuyến huyện miền tây nên mô hình bệnh tật của bệnh viện khá đa dạng, tỷ lệ mắc một số bệnh có chì định sử dụng thuốc kháng sinh trong mô hình bềnh tật tại bệnh viện năm 2018 gồm: bệnh hệ hố hấp $(25,91 \%)$, nhiễm khuẩn và ký sinh vật $(1,62 \%)$, tiết niệu - sinh dục $(1,88 \%)$... Phẩn tích thuốc kháng sinh sử dụng tại bệnh viện năm 2018 nhằm mục tiêu mô tả cở cấu các thuốc kháng sinh đã sử dụng theo một số chỉ tiêu để chỉ ra một số tồn tại trong sử dụng thuốc kháng sinh làm cơ sở cho việc đề xuất các biện pháp quản lý và giám sát sử dụng kháng sinh hợp lý tại bệnh viện trong những năm tiếp theo.

\section{II. ĐỐI TƯỢNG VÀ PHƯƠNG PHÁP NGHIÊN CỨU}

2.1 Đối tượng nghiên cứu. Toàn bộ thuốc kháng sinh gồm 56 khoản mục trong số 419 khoản mục thuốc đã sử dụng tại Bệnh viện đa khoa huyện Vĩnh Thuận, tỉnh Kiên Giang được xuất từ Khoa Dược năm 2018.

2.2. Phương pháp nghiên cứu: Mô tả cắt ngang hồi cứu

Xử lý số liệu: Số liệu được kết xuất ra file Excel, liếu DDD của mỗi thuốc kháng sinh được 
tra cứu theo khuyến cáo của WHO[6]. Sử dụng phương pháp phân tích tỷ trọng, phương pháp tính liều $\mathrm{DDD}^{[1][4]}$.

\section{KẾT QUẢ NGHIÊN CỨU}

3.1. Tỷ lệ khoản mục và giá trị thuốc kháng sinh sử dụng tại bệnh viện đa khoa huyện Vĩnh Thuân năm 2018.

Bảng 3.1. Tỷ lệ thuốc kháng sinh sử dụng tại bệnh viện đa khoa huyện Vïnh Thuận

\begin{tabular}{|c|c|c|c|c|}
\hline Nhóm thuốc & Số khoản mục & \% khoản & Giá trị (1000 đ) & \% giá trị \\
\hline Thuốc kháng sinh & 56 & 13,4 & 4.322 .644 & 27,3 \\
\hline Thuốc khác & 363 & 86,6 & 11.500 .481 & 72,7 \\
\hline Tống & $\mathbf{4 1 9}$ & $\mathbf{1 0 0 , 0}$ & $\mathbf{1 5 . 8 2 3 . 1 2 5}$ & $\mathbf{1 0 0 , 0}$ \\
\hline
\end{tabular}

Năm 2018, bệnh viện đa khoa huyên Vĩnh Thuận đã sử dụng 419 khoản mục thuốc, trong đó thuốc kháng sinh sử dụng là 56 khoản với giá trị tương ứng 4,322 tỷ đồng chiếm 27,3\% tổng giá trị tiền thuốc sử dụng tại bệnh viện.

3.2. Cơ cấu thuốc kháng sinh sử dụng tại bệnh viện đa khoa huyện Vĩnh Thuận.

\section{Bảng 3.2: Cơ cấu thuốc kháng sinh sử dung tai bểnh viênn}

\begin{tabular}{|c|c|c|c|c|c|}
\hline TT & Nhóm thuốc & Số khoản mục & \% khoản & Giá trị (1000 đ) & \% giá trị \\
\hline \multicolumn{6}{|c|}{ Theo nguồn gốc } \\
\hline 1 & Sản xuất trong nước & 47 & 83,93 & 3.679 .806 & 85,13 \\
\hline 2 & Nhập khẩu & 9 & 16,07 & 642.838 & 14,87 \\
\hline \multicolumn{6}{|c|}{ Theo đối tượng sử dụng } \\
\hline 3 & Nội trú & 45 & 80,36 & 1.518 .945 & 35,14 \\
\hline 4 & Ngoại trú & 36 & 64,29 & 2.803 .699 & 64,86 \\
\hline \multicolumn{6}{|c|}{ Theo thành phần } \\
\hline 5 & Đơn thành phần & 54 & 96,43 & 4.319 .737 & 99,93 \\
\hline 6 & Đa thành phần & 2 & 3,57 & 2.907 & 0,07 \\
\hline \multicolumn{6}{|c|}{ Theo đường dùng } \\
\hline 7 & Đường uống & 27 & 48,21 & 2.843 .095 & 65,77 \\
\hline 8 & Đường tiềm, truyền & 13 & 23,21 & 996.221 & 23,05 \\
\hline 9 & Đường khác & 16 & 28,58 & 483.328 & 11,18 \\
\hline \multicolumn{6}{|c|}{ Theo tên thuốc } \\
\hline 10 & Thuốc generic & 52 & 92,86 & 4.229 .359 & 97,84 \\
\hline 11 & Thuốc biệt dược gốc & 4 & 7,14 & 93.285 .020 & 2,16 \\
\hline \multicolumn{6}{|c|}{ Theo phân nhóm kháng sinh } \\
\hline 12 & Các cephalosporin & 23 & 41,07 & 2.255 .662 & 52,28 \\
\hline 13 & Các penicillin & 5 & 8,93 & 1.499 .329 & 34,69 \\
\hline 14 & Quinolon & 14 & 25,00 & 438.358 & 10,14 \\
\hline 15 & Macrolid & 2 & 3,57 & 16.856 & 0,39 \\
\hline 16 & Aminosid & 4 & 7,14 & 50.757 & 1,17 \\
\hline 17 & Phenicol & 1 & 1,79 & 2.134 & 0,05 \\
\hline 18 & Nhóm khác & 7 & 12,50 & 59.548 & 1,38 \\
\hline & Tống & 56 & 100,00 & 4.322 .644 & 100.00 \\
\hline
\end{tabular}

Năm 2018, tai bênh viên đa khoa huyên Vĩnh Thuận sử dụng kháng sinh sản xuất trong nước chiếm $85,13 \%$ giá trị của $83,93 \%$ khoản mục. Mặc dù kháng sinh điều trị nội trú chiếm 80,36\% khoản nhưng xét về giá trị thì kháng sinh điêu trị ngoại trú lại chiếm tỷ lệ cao hơn (chiếm 64,86\%). Thuốc kháng sinh đơn thành phần được sử dụng chủ yếu với $96,43 \%$ khoản mục tương ứng $99,93 \%$ giá trị, kháng sinh đa thành phần có 2 khoản mục của phối hợp các kháng sinh metronidazol + neomycin + nystatin dạng thuốc đặt là hợp lý. Xem xét về đường dùng thuốc kháng sinh tại bệnh viện cho thấy, bệnh viện sử dụng nhiều nhất là đường uống phù hợp với bệnh viện hạng 3 có lượng bệnh nhân ngoại trú nhiều, tỷ lệ giá trị thuốc kháng sinh đường uống chiếm $65,77 \%$. Thuốc kháng sinh generic chiếm chủ yếu với tỷ lệ giá trị là $97,84 \%$. Kháng sinh betalactam gồm penicillin và cephalosporin chiếm tỷ lệ cao về giá trị tương ứng 34,69\% và 52,28\%.

3.3. Giá trị sử dụng các kháng sinh dùng đường tiêm tại bệnh viện 
Bảng 3.3: Danh mục các thuốc kháng sinh đường tiêm sử dụng tại bệnh viện

\begin{tabular}{|c|c|c|c|c|c|c|}
\hline Hoạt chất & Tên thuốc & $\begin{array}{c}\text { Đơn vi } \\
\text { tính }\end{array}$ & $\begin{array}{c}\text { Số lượng sữ } \\
\text { dụng }\end{array}$ & $\begin{array}{l}\text { Đơn giá } \\
\text { (VNĐ) }\end{array}$ & $\begin{array}{c}\text { Thành tiến } \\
\text { (VND) }\end{array}$ & $\begin{array}{c}\% \\
\text { Giá trị }\end{array}$ \\
\hline \multirow{2}{*}{ Ceftazidim } & Zidimbiotic 1000 & Lọ & 20.570 & 17.997 & 370.198 .290 & \multirow{2}{*}{38,77} \\
\hline & Zidimbiotic 2000 & Lo & 473 & 33.999 & 16.081 .527 & \\
\hline Ceftizoxim & Ceftizoxim 1g & Lo & 16.614 & 18.358 & 304.999 .812 & 30,62 \\
\hline \multirow{2}{*}{ Ceftriaxon* } & Triaxobiotic 2000 & Lọ & 2.924 & 28.980 & 84.737 .520 & \multirow{2}{*}{11,68} \\
\hline & Ceftriaxon $1 \mathrm{~g}$ & Lọ & 3.983 & 7.928 & 31.577 .224 & \\
\hline Amikacin & Amikacin $500 \mathrm{mg} / 100 \mathrm{ml}$ & Chai & 798 & 50.400 & 40.219 .200 & 4,04 \\
\hline \multirow{2}{*}{ Cefotaxim } & Taxibiotic 1000 & LO & 3.737 & 9.093 & 33.980 .541 & \multirow[b]{2}{*}{4,83} \\
\hline & Cefotaxime $1 \mathrm{~g}$ & Lọ & 2.297 & 6.148 & 14.121 .956 & \\
\hline \multirow[t]{2}{*}{ Ciprofloxacin } & $\begin{array}{l}\text { Ciprofloxacin Kabi } \\
200 \mathrm{mg} / 100 \mathrm{ml}\end{array}$ & Chai & 1.401 & 16.800 & 800 & \multirow[t]{2}{*}{4,25} \\
\hline & Basmicin 400mg/200ml & Chai & 200 & 94.000 & 18.800 .000 & \\
\hline Amoxicillin & Vimotram $1,5 \mathrm{~g}$ & Lọ & 588 & 43.500 & .000 & 2,57 \\
\hline \multirow{2}{*}{ Vancomicin } & Vancomicin $500 \mathrm{mg}$ & Lọ & 799 & 29.400 & 23.490 .600 & \multirow{3}{*}{$\frac{3,25}{100,00}$} \\
\hline & Vancorin injection $1 \mathrm{~g}$ & Lọ & 100 & 89.000 & 8.900 .000 & \\
\hline Tống & & & & & 996.221.470 & \\
\hline
\end{tabular}

Kháng sinh đường tiêm, truyền được sử dụng tạo bệnh viện đa khoa huyện Vĩnh Thuận năm 2018 gồm 8 hoạt chất (ceftazidim, ceftizoxim, ceftriaxon, amikacin, cefotaxim, ciprofloxacin, amoxicillin, vancomicin) của 13 thuốc, trong đó ceftazidim và ceftizoxim là hai kháng sinh được sử dụng với giá trị cao nhất và số lượng sử dụng nhiều nhất (21.043 lọ ceftazidim và 16.614 lọ ceftizoxim).

3.4. Số DDD/100 giường ngày của các phân nhóm kháng sinh trong điêu trị nội trú Bảng 3.4. Số DDD/100 giường ngày của các phân nhóm kháng sinh trong điêu trị nội trú

\begin{tabular}{|c|c|c|c|}
\hline Phân nhóm kháng sinh & Mã ATC & Tống số DDD & DDD/100 giường ngày \\
\hline Cephalosporin & $\mathrm{J} 01 \mathrm{D}$ & $\mathbf{2 9 1 6 8 , 1 3}$ & 27,556 \\
\hline Penicillin & $\mathrm{J} 01 \mathrm{C}$ & 3997,92 & 3,777 \\
\hline Quinolon & $\mathrm{J} 01 \mathrm{M}$ & 3272,11 & 3,091 \\
\hline Macrolid & $\mathrm{J} 01 \mathrm{~F}$ & 285,83 & 0,270 \\
\hline Aminosid & $\mathrm{J} 01 \mathrm{G}$ & 399,43 & 0,377 \\
\hline Phenicol & $\mathrm{J} 01 \mathrm{~B}$ & 2,06 & 0,002 \\
\hline Nhóm khác & & 805,48 & 0,761 \\
\hline Tống & & $\mathbf{3 7 . 9 3 0 , 9 6}$ & $\mathbf{3 5 , 8 3 5}$ \\
\hline
\end{tabular}

Số $\mathrm{DDD} / 100$ giường ngày của kháng sinh trong điều trị nội trú tại bệnh viện đa khoa huyện Vĩnh Thuận năm 2018 là 35,835 DDD, trong đó phân nhóm cephalosporin cao nhất là 27,556 DDD. Bệnh viện sử dụng kháng sinh chủ yếu 3 phân nhóm: cephalosporin, penicillin, quinolon.

3.5. Số DDD/bệnh nhân nội trú của mười kháng sinh

Bảng 3.5. Số DDD/bệnh nhân nội trú của mười kháng sinh có DDD/100 giường ngày cao nhất

\begin{tabular}{|c|c|c|c|c|c|}
\hline Kháng sinh & $\begin{array}{c}\text { Đường } \\
\text { dùng }\end{array}$ & $\begin{array}{c}\text { Số DDD/100 } \\
\text { giường ngày }\end{array}$ & $\begin{array}{c}\text { Tống số } \\
\text { DDD }\end{array}$ & $\begin{array}{c}\text { Số bê̂nh nhân } \\
\text { sử dụng }\end{array}$ & $\begin{array}{c}\text { Số DDD/ } \\
\text { bệnh nhấn }\end{array}$ \\
\hline Cefadroxil & Uống & 6,34 & 6708,00 & 2006 & 3,34 \\
\hline Ceftazidim & Tiêm & 5,91 & 6250,75 & 4030 & 1,55 \\
\hline Ceftriaxon* & Tiêm & 4,82 & 5102,50 & 1252 & 4,07 \\
\hline Ceftizoxim & Tiêm & 3,92 & 4153,75 & 2432 & 1,71 \\
\hline Amoxicillin & Uống & 3,78 & 3997,92 & 1248 & 3,20 \\
\hline Cefuroxim & Uống & 2,32 & 2459,50 & 729 & 1,79 \\
\hline Levofloxacin* & Tiêm & 1,70 & 1795,00 & 287 & 6,25 \\
\hline Cefaclor & Uống & 1,64 & 1733,25 & 684 & 2,53 \\
\hline Cefotaxim & Tiêm & 1,53 & 1616,75 & 1362 & 1,19 \\
\hline Cefixim & Uống & 0,89 & 940,25 & 1118 & 0,84 \\
\hline
\end{tabular}

Trong 10 kháng sinh điều trị nọi trú có $\mathrm{DDD} / 100$ giường ngày cao nhất có 2 kháng sinh phải hội chẩn khi sử dụng (ceftriaxon và levofloxacin). Số DDD/bệnh nhân cho thấy ban đầu về tính hợp lý về thời gian sử dụng của kháng sinh. Kết quả khảo sát cho thấy một số 
kháng sinh có thời gian điều trị ngắn hơn so với khuyến cáo như: ceftazidim (1,55 DDD), ceftizoxim (1,71 DDD), cefuroxim (1,79 DDD), cefotaxim (1,19 DDD), cefixim (0,84 DDD).

\section{BÀN LUẬN}

Chi phí tiền thuốc kháng sinh trong bệnh viện là một chỉ số được các nhà quản lý bệnh viện quan tâm trong hoạt động giám sát sử dụng kháng sinh hợp lý, bệnh viện đa khoa huyện Vĩnh Thuận năm 2018 có tỷ lệ chi phí tiền thuốc kháng sinh chiếm $27,3 \%$, tỳ lệ này thấp hơn so với một số bệnh viện tương tự như Trung tâm y tế huyện An Phú, tỉnh An Giang có tỷ lệ chi phí kháng sinh chiếm $29,9 \%{ }^{[3]}$, bệnh viện chuyên khoa như bệnh viện Phạm Ngọc Thạch $(39,3 \%)^{[5]}$. Tuy nhiên cơ câu thuốc kháng sinh sử dụng cần được làm rõ để phát hiện những bất cập trong sử dụng thuốc kháng sinh tại bệnh viện. Cơ cấu thuốc kháng sinh sử dụng tại bệnh viện đa khoa huyện Vĩnh Thuận có ưu tiên sử dụng kháng sinh sản xuất trong nước với tỷ lệ về giá trị chiếm trên $85 \%$, thuốc kháng sinh đơn thành phần chiếm 99,93\% giá trị, điều này cũng phù hợp với chính sách chung của Bộ y tế trong việc ưu tiên sử dụng thuốc sản xuất trong nước và ưu tiên sử dụng thuốc đơn thành phần ${ }^{[1]}$.

Tại các bệnh viện tuyến huyện, đối tượng khám và điều trị ngoại trú nhiều hơn, vì thế tỷ lệ chi phí kháng sinh của đối tượng ngoại trú tại bệnh viện đa khoa huyện Vỉnh Thuận chiếm 64,86\%, tương tự như tại Trung tâm y tế huyện An Phú có tỷ lệ giá trị thuốc kháng sinh dùng trong ngoại trú chiếm $71,6 \%{ }^{[3]}$. Và đường dùng chủ yếu tại các cơ sở này là đường uống là hợp lý: $65,77 \%$ giá trị kháng sinh đường uống tại bệnh viện đa khoa huyện Vĩnh Thuận; $76,4 \%$ giá trị kháng sinh đường uống tại Trung tâm y tế huyện An Phú[3].

Chỉ số DDD/100 giường - ngày của kháng sinh là một chỉ số đánh giá sử dụng kháng sinh. Tại bệnh viện đa khoa huyện Vinh Thuận có số $\mathrm{DDD} / 100$ giường- ngày của kháng sinh là 35,835 , thấp hơn so với cơ sở y tế cùng hạng là Trung tâm y tế huyện An Phú $(51,28$ DDD/100 giường - ngày ${ }^{[3]}$, điều đó phần nào cho thấy bệnh viện đa khoa huyện Vĩnh Thuận đã hạn chế sử dụng kháng sinh. Tuy nhiên việc hạn chế này dường như chưa hợp lý khi xem xét số $\mathrm{DDD} /$ bênh nhân cho thấy với 10 kháng sinh khảo sát đều có chỉ số này thấp có thể do việc sử dụng kháng sinh chưa phù hợp với khuyến cáo về thời gian sử dụng (thấp hơn so với khuyến cáo), điều đó cũng cần có hướng dẫn cụ thể hơn tại bệnh viện về sử dụng kháng sinh tránh tình trạng sử dụng không đủ thời gian sẽ dẫn đến vi khuẩn kháng kháng sinh.

Nhằm quản lý sử dụng kháng sinh trong bệnh viện những năm tiếp theo, bệnh viện cần phân công dược sĩ chịu trách nhiệm trong hoạt động cải thiện sử dụng kháng sinh. Năm 2018, bệnh viện đa khoa huyện Vĩnh Thuận đã sử dụng một số kháng sinh cần giám sát chặt chẽ (kháng sinh có dấu *), thời gian tiếp theo bệnh viện cần tiến hành phân loại phân loại kháng sinh tham khảo hướng dẫn của WHO (nhóm tiếp cận, nhóm theo dõi, nhóm dự trữ) ${ }^{[7]}$ và theo hướng dẫn của Bô y tế (nhóm 1, nhóm 2, nhóm 3$)^{[2]}$ nhằm ưu tiên trong quản lý sử dụng kháng sinh, duy trì việc theo dõi tình hình sử dụng kháng sinh qua phẩn tích DDD, chi phí sử dụng kháng sinh...

\section{KẾT LUÂ̂N}

Năm 2018, bệnh viện đa khoa huyện Vĩnh Thuận, tỉnh Kiên Giang sử dụng 56 khoản mục kháng sinh với giá trị chiếm $27,3 \%$ tổng giá trị tiền thuốc. Thuốc sản xuất trong nước chiếm $83,93 \%$ khoản mục; $85,13 \%$ giá trị. Thuốc kháng sinh điều trị ngoại trú chiếm $64,86 \%$ giá tri. Kháng sinh đơn thành phần chiếm 99,93\% giá trị; $96,43 \%$ khoản mục. Bệnh viện sử dụng nhiều kháng sinh đường uống $(65,77 \%$ giá trị), đơn thành phần $(96,43 \%$ khoản; $99,93 \%$ giá trị). Các cephalosporin sử dụng nhiều nhất (41,07\% khoản; $52,28 \%$ giá trị). Số DDD/100 giường - ngày của kháng sinh điều trị nội trú là 35,835 DDD. Số DDD/bệnh nhân của một số kháng sinh khảo sát còn thấp như: ceftazidim, ceftizoxim, cefuroxim, cefotaxim, cefixime.

\section{TÀI LIÊU THAM KHẢO}

1. Bộ y tế (2013), Thông tư $21 / 2013 / T T$-BYT ngày 8/8/2013 Quy định về tổ chức và hoạt động của Hô̂i đồng Thuốc và điều trị trong bênh viện;

2. Bộ y tế (2020), Quyết đinh số 5631/QĐ-BYT ngày $31 / 12 / 2020$ của Bộ y tế $V / v$ ban hành tài liệu "Hướng dấn thực hiện quản lý sử dụng kháng sinh trong bệnh viện"'

3. Nguyễn Thị Thanh Hương, Đoàn Văn Giang (2020), Phân tích danh muc thuốc kháng sinh sứ dựng tại Trung tâm y tế huyện An Phú, tỉnh An Giang nẳm 2018, Tạp chí Dược học số 528 trang 15-18

4. Tổ chức y tế thế giới (2004), Hội đồng thuốc và điêuu trị - Cẩm nang hướng dấn thực hành, trang 87 - 89;

5. Nguyễn Thị Mai Trang (2020), Phân tích thực trạng sử dụing kháng sinh tại bệnh viện Phạm Ngọc Thạch năm 2018, Luận văn dược sĩ chuyên khoa 2, Trường Đại học Dược Hà Nội;

6. WHO (2014), Guidelines for ATC classification and DDD assignment;

7. WHO (2017), Model list of Essential Medicines (EML) $20^{\text {th }}$ 